\title{
Macrophage Inflammatory Protein-2 in High Mobility Group Box 1 Secretion of Macrophage Cells Exposed to Lipopolysaccharide
}

\author{
Qin Chaochao ${ }^{a}$ Guohua Lou ${ }^{a}$ Ying Yanga Yanning Liu ${ }^{a}$ Ying Hua Zheng Mina \\ Ping Chen ${ }^{\mathrm{a}}$ Jiliang $\mathrm{He}^{\mathrm{b}}$ Zhi Chen ${ }^{\mathrm{a}}$

\begin{abstract}
aState Key Laboratory for Diagnosis and Treatment of Infectious Diseases, The First Affiliated Hospital, School of Medicine, Zhejiang University Collaborative Innovation Center for Diagnosis and Treatment of Infectious Diseases, 'bepartment of Environmental Medicine, School of Public Health, Zhejiang University, Hangzhou, China
\end{abstract}

\section{Key Words}

Macrophage inflammatory protein-2 • Acute inflammation • Macrophages • HMGB1

\begin{abstract}
Background/Aims: Macrophage inflammatory protein-2 (MIP-2), a type of leukocyte chemokine, is primarily produced by macrophages, and levels increase significantly in early inflammation. However, the precise biological functions and mechanisms of MIP-2 in the development of inflammation remain unclear. The purposes of the present study were to investigate the role of MIP-2 in inflammation induced by lipopolysaccharide (LPS) in vitro and to determine the possibility of blocking the high mobility group box 1 (HMGB1) signalling pathway via MIP-2 inhibition. Methods: Macrophage cells (RAW264.7, U937 and THP-1 cells) were divided into control and treatments groups. Expression levels of interleukin- 6 (IL-6), interleukin-1 $\beta$ (IL-1 $\beta$ ), tumour necrosis factor- $\alpha$ (TNF- $\alpha$ ), HMGB1, chemokine (C-C motif) ligand-2 (Ccl-2), Toll-like receptor-4 (TLR-4), inducible nitric oxide synthase (iNOS), phosphorylated MAPKs (p38, ERKs, JNKs), PI3K/Akts, JAKs/STAT3, IKB, and cytoplasmic and nuclear NF-KB p65 in RAW264.7 cells were detected by qRT-PCR, enzyme-linked immunosorbent assay (ELISA) or western blot assays. Results: mip-2 siRNA and an anti-MIP-2 antibody significantly reduced the expression levels of Ccl-2, TLR-4, iNOS, IL-6, IL-1ß, HMGB1, and TNF- $\alpha$ in RAW264.7 cells exposed to LPS $(P<0.01)$. Additionally, mRNA expression levels of HMGB1 and TLR-4 in cells treated with LPS+mip-2 siRNA were significantly lower than those in cells treated with LPS alone $(P<0.01$ or $P<0.05)$. The MIP-2 antibody significantly suppressed activation of p38-MAPK, p-STAT3, and p-Akts and translocation of NF-kB p65 from the cytoplasm to the nucleus in RAW264.7 exposed to LPS $(P<0.01$ or $P<0.05)$. Conclusion: mip-2 siRNA and the MIP-2 antibody can reduce the inflammatory effects induced by LPS in macrophage cells. The mechanisms may occur through down-regulation of p38-MAPK, STAT3 and Akts phosphorylation and translocation of NF-KB p65. MIP-2 plays an important role in inflammation induced by LPS.

(C) 2017 The Author(s)

Published by S. Karger AG, Basel




\section{Introduction}

Lipopolysaccharide (LPS), a pathogen-associated molecular pattern (PAMP), can trigger a cascade of inflammatory processes. Binding of LPS to Toll-like receptor 4 (TLR-4) on macrophages initiates signalling that leads to more intricate biological responses, including the secretion of a number of pro-inflammatory mediators, and disturbs normal body function, resulting in liver injury, infarction, cardiovascular diseases, neurodegenerative disorders or even death [1-7].

MIP-2, a member of the CXC chemokine family, is a peptide derived from monocytes/ macrophages, and can recruit neutrophils to infection sites [8]. Members of the chemokine family with the ability to mediate leukocyte chemotaxis can be classified into four subgroups according to the location of a cysteine in the polypeptide chain: C, CC, CXC, and CX3C [9, 10]. To date, at least 50 chemokines that exhibit various physiological and pathological properties have been identified, most of which belong to the CC and CXC subgroups [11]. Migration of neutrophils is primarily mediated by MIP-2, and Hu, B. and Devalaraja, et al. observed inhibition of neutrophil migration in response to LPS in CXCR2-knockout mice and in mice with CXCR2 specifically blocked by an antagonist $[12,13]$. Thus, MIP-2 release has an important impact on the development of early immune responses. MIP- 2 is mainly produced by macrophages, one of the most dominant and widely distributed inflammatory cells, and is involved in the initiation and maintenance of the acute inflammatory response [14]. Indeed, macrophages are central players in inflammation and the immune response; when exposed to LPS, TLR-4 on macrophages recognizes LPS and causes cell activation, including the production of NO and pro-inflammatory cytokines such as TNF- $\alpha$ and IL-6 [12, 15].

HMGB1 is constitutively expressed in quiescent macrophages/monocytes, stored in the nucleus, actively secreted from stimulated macrophages, and passively released from injured cells. HMGB1 was originally recognized as an intranuclear protein that functions in the maintenance of nucleosome structure, chromatin remodelling, and the regulation of gene transcription [16]. In addition, extracellular HMGB1 can play a critical role in the pathogenesis of inflammation with or without infection. Extracellular HMGB1 under various pathologic states is largely derived from a passive release pathway related to the death and decomposition of cells or an active pathway in live cells such as macrophages/monocytes [17-19]. HMGB1 is a DNA-binding protein that possesses cytokine-like, pro-inflammatory properties. Cell surface receptors that engage in HMGB1 interaction include RAGE, TLR-4 and TLR-2. Macrophage activation by HMGB1 results in cytokine secretion; when released into the extracellular milieu, HMGB1, as a potent pro-inflammatory cytokine, activates a wide range of inflammatory responses, including massive production of chemokine adhesion molecules (e.g., ICAM-1, VCAM-1) and cytokines (e.g., TNF- $\alpha$, IL-1 $\beta$, NO) [16, 17, 20, 21]. In recent years, some experimental and clinical data have highlighted the contributions of extracellular HMGB1 to the pathogenesis of many inflammatory and cancer diseases.

Kollmar, 0., et al. previously reported that antibody neutralization of MIP-2 or KC significantly reduced the levels of these pro-inflammatory cytokines in liver tissue and influx of neutrophils to the liver [22]. However, it remains unclear whether MIP-2 has an effect on HMGB1 secretion in RAW264.7 cells. Moreover, Zhou, H., et al. previously demonstrated that Gu-4 significantly attenuated the HMGB1 mRNA expression levels in RAW264.7 cells exposed to LPS, which promotes the aggravation of inflammation [23]. It was assumed that MIP-2 critically contributes to HMGB1 release; thus, it is necessary to conduct experiments to determine whether inhibition of MIP-2 secretion by silencing or neutralizing MIP-2 could ameliorate HMGB1 expression and release of other pro-inflammatory cytokines. In present study, siRNA targeting MIP-2 was used to specifically knock down mip-2 mRNA, and an antiMIP-2 antibody was applied to neutralize the MIP-2 protein. The levels of pro-inflammatory cytokines and HMGB1 were then measured. The aims this study were to investigate the role of MIP-2 in inflammation induced by LPS in vitro and to determine the possibility of blocking the HMGB1 signalling pathway by MIP-2 inhibition using mip-2 siRNA or an anti-MIP-2 antibody.

\section{KARGER}




\section{Cellular Physiology Cell Physiol Biochem 2017;42:913-928 and Biochemistry Published online: June 26, $2017 \quad \begin{aligned} & \text { DOI: 10.1159/000478646 } 2017 \text { The Author(s). Published by S. Karger AG, Basel } \\ & \text { www.karger.com/cpb }\end{aligned}$ Chaochao et al.: MIP-2 in HMGB1 Secretion}

\section{Material and Methods}

\section{Cells and Reagents}

The murine macrophage cell line (RAW264.7 cells) was obtained from American Type Culture Collection (ATCC, Rockville, MD, USA); U937 cells (human mononuclear macrophage cell line) and THP-1 cells (human acute monocyte leukaemia cell line) were purchased from the CBCAS (Cell Bank of the Chinese Academic of Sciences, Shanghai, China). LPS (purified lyophilized powder) was purchased from SigmaAldrich (St. Louis, USA). The monoclonal rat anti-mouse MIP-2 monoclonal antibody (MAB452, R\&D Systems, Inc., Minneapolis, MN) and isotype control antibodies (rat IgG2b) were purchased from R\&D Systems (the USA). MAPK inhibitors SP600125, PD98059, and SB203580 and the PI3K/Akts inhibitor LY294002 were obtained from BioGems. The JAK/STAT inhibitor AG490 was obtained from Calbiochem (catalogue number 658401). The HMGB1 inhibitor ethyl pyruvate (EP) was purchased from Sigma-Aldrich (St. Louis, MO, USA); the solution was prepared with sodium (130 mM), potassium (4 mM), calcium (2.7 mM), chloride (139 mM), and EP (28 mM) (pH 7.0).

Gene silencing of murine mip-2 mRNA

A specific siRNA targeting the murine mip-2 mRNA and universal negative mismatched control scramble siRNA were obtained from RiboBio (Guangzhou, China); their sequences are as follows: duplex\# 1AACGAUUCGCUAAUUCACUGU; duplex\# 2AAGCAGUCGGAUGGCUUUCAU". RAW264.7 cells were transfected with $25 \mathrm{nmol} / \mathrm{ml}$ annealed siRNA or control scramble siRNA in serum-free Opti-MEM I medium using Lipofectamine 3000 reagent (Invitrogen) as the transfection reagent according to the manufacturer's instruction. At $24 \mathrm{~h}$ after transfection, the RAW 264.7 cells were exposed to LPS for $24 \mathrm{~h}$.

Detection of IL-6, TNF- $\alpha, I L-1 \beta$ and HMGB1 protein expression using ELISA

IL-6, TNF- $\alpha$, and IL-1 $\beta$ were detected by ELISA in following groups: (1) normal control, LPS $(0.0625$, $0.125,0.25,0.50$, and $1.0 \mu \mathrm{g} / \mathrm{ml})$, LPS+mip-2 siRNA $(0.0625,0.125,0.25,0.50$, and $1.0 \mu \mathrm{g} / \mathrm{ml} \mathrm{LPS}$ plus 25 $\mathrm{nmol} / \mathrm{ml}$ mip-2 siRNA), LPS+scramble siRNA (0.0625, 0.125, 0.25, 0.50, and $1.0 \mu \mathrm{g} / \mathrm{ml}$ LPS plus $25 \mathrm{nmol} / \mathrm{ml}$

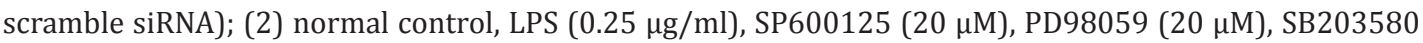

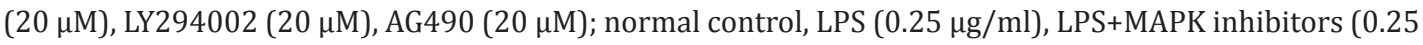
$\mu \mathrm{g} / \mathrm{ml}$ LPS plus $20 \mu \mathrm{M}$ each SP600125, PD98059, and SB-203580), LPS+PI3K/Akt inhibitor LY294002 (0.25 $\mu \mathrm{g} / \mathrm{ml}$ LPS plus $20 \mu \mathrm{M}$ LY294002), LPS+JAK/STAT inhibitor AG490 (0.25 $\mu \mathrm{g} / \mathrm{ml}$ LPS plus $20 \mu \mathrm{M}$ AG490) groups; (3) normal control, LPS $(0.25 \mu \mathrm{g} / \mathrm{ml})$, LPS+EP $(0.25 \mu \mathrm{g} / \mathrm{ml}$ LPS plus $10 \mathrm{mM}$ EP for 0, 6, 12, 18, 24, $30 \mathrm{~h})$; normal control, LPS $(0.25 \mu \mathrm{g} / \mathrm{ml})$, LPS+ MIP-2 antibody $(0.25 \mu \mathrm{g} / \mathrm{ml}$ LPS plus $1.0 \mu \mathrm{g} / \mathrm{ml} \mathrm{mip-2}$ antibody for 2, 4, 6, 8, 10, $12 \mathrm{~h}$ ); (4) normal control, recombinant MIP-2 (rMIP-2) (30 ng/ml; R\&D Systems, Minneapolis, MN); normal control, LPS $(0.25 \mu \mathrm{g} / \mathrm{ml})$, LPS+MIP-2 antibody $(0.25 \mu \mathrm{g} / \mathrm{ml}$ LPS plus $1.0 \mu \mathrm{g} / \mathrm{ml}$ MIP-2 antibody), LPS+IgG (0.25 $\mu \mathrm{g} / \mathrm{ml}$ LPS plus $1.0 \mu \mathrm{g} / \mathrm{ml}$ IgG), LPS+rMIP-2 (0.25 $\mu \mathrm{g} / \mathrm{ml}$ LPS plus $30 \mathrm{ng} /$ ml rMIP-2).

HMGB1 was detected using an ELISA kit (Cloud Clone Corp, Houston, TX) for the following groups: (1) normal control, rMIP-2 (30 ng/ml); (2) normal control, LPS $(0.25 \mu \mathrm{g} / \mathrm{ml})$, LPS+ MIP-2 antibody $(0.25 \mu \mathrm{g} / \mathrm{ml}$ LPS plus $1.0 \mu \mathrm{g} / \mathrm{ml}$ MIP-2 antibody), LPS+IgG (0.25 $\mu \mathrm{g} / \mathrm{ml}$ LPS plus $1.0 \mu \mathrm{g} / \mathrm{ml}$ IgG), LPS+rMIP-2 (0.25 $\mu \mathrm{g} / \mathrm{ml}$ LPS plus $30 \mathrm{ng} / \mathrm{ml} \mathrm{rMIP}-2)$.

The exposure time for RAW 264.7 cells was $2 \mathrm{~h}$ or $24 \mathrm{~h}, 100 \mu \mathrm{l}$ of culture supernatant or reagent diluent standard were added to each well. ELISA kits for IL-1 $\beta$, TNF- $\alpha$ and IL-6 (Dakewe Biotech Company Limited, Beijing, China) were used for detection. Absorbance was measured at $450 \mathrm{~nm}$ using a microtitre plate reader (Bio-Rad, Hercules, CA) [24], and protein levels were calculated on the basis of standard curves. MIP-2 protein levels in culture supernatants were measured using rat MIP-2 ELISA kits (RayBiotech, Inc., Norcross, GA).

Measuring the mRNA expression levels of HMGB1, IL-1 $\beta, I L-6$, mip-2, TNF- $\alpha$, iNOS, Ccl-2 and TLR-4 using qRT-PCR

Cells used for detecting mip-2 were divided into the following groups: normal control, LPS $(0.25 \mu \mathrm{g} /$ ml), LPS+mip-2 siRNA (0.25 $\mu \mathrm{g} / \mathrm{ml}$ LPS plus $25 \mathrm{nmol} / \mathrm{ml}$ mip-2 siRNA) and LPS+scramble siRNA (0.25 $\mu \mathrm{g} /$ $\mathrm{ml}$ LPS plus $25 \mathrm{nmol} / \mathrm{ml}$ scramble siRNA). 


\section{Cellular Physiology Cell Physiol Biochem 2017;42:913-928 \begin{tabular}{l|l} 
and Biochemistry Published online: June 26, 2017 & $\begin{array}{l}\text { C } 2017 \text { The Author(s). Published by S. Karger AG, Basel } \\
\text { www.karger.com/cpb }\end{array}$
\end{tabular} \\ Chaochao et al.: MIP-2 in HMGB1 Secretion}

Table 1. List of primers

\begin{tabular}{lll}
\hline & sense & antisense \\
\hline HMGB1 & AGCCCTGTCCTGGTGGTATTTTCAA & GCTGTGCACCAACAAGAACCTGC \\
TLR-4 & ACCTGGCTGGTTTACACGTC & CTGCCAGAGACATTGCAGAA \\
$\beta$-actin & GTGACGTTGACATCCGTAAAGA & GCCGGACTCATCGTACTCC \\
mip-2 & GGAAGCCTGGATCGTACCTG & AACAACATCTGGGCAATGGA \\
IL-1 $\beta$ & TGAAATGCCACCTTTTGACAG & CCACAGCCACAATGAGTGATAC \\
IL-6 & TTCCATCCAGTTGCCTTCTT & CAGAATTGCCATTGCACAAC \\
TNF- $\alpha$ & TCTTCTCATTCCTGCTTGTGG & CACTTGGTGGTTTGCTACGAC \\
iNOS & CTCACTGGGACAGCACAGAA & TGGTCAAACTCTTGGGGTTC \\
Ccl-2 & GGCTGGAGAGCTACAAGAGG & ATGTCTGGACCCATTCCTTC \\
\hline
\end{tabular}

Cells used for detecting HMGB1, IL-1 $\beta$, IL-6, TNF- $\alpha$, iNOS, Ccl- 2 and TLR- 4 were divided into the following groups: (1) normal control, (2) LPS+mip-2 siRNA (0.25 $\mu \mathrm{g} / \mathrm{ml}$ LPS plus $25 \mathrm{nmol} / \mathrm{ml}$ mip-2 siRNA) and (3) LPS+scramble siRNA $(0.25 \mu \mathrm{g} / \mathrm{ml}$ LPS plus $25 \mathrm{nmol} / \mathrm{ml}$ scramble siRNA).

After incubation with LPS, total RNA was prepared from RAW264.7 cells using Trizol reagent (Invitrogen, Corp., Carlsbad, USA) [25, 26]. Quantitative determination of total RNA was conducted using the GeneQuant pro RNA/DNA Calculator spectrophotometer (Amersham Biosciences, Freiburg, Germany). Total RNA (100 ng) was reverse transcribed using PrimeScript ${ }^{\mathrm{TM}}$ RT reagent Kit with gDNA Eraser (Code no. RR047A, Takara).

$\beta$-actin was used for normalization of the total mRNA input and the efficiency of cDNA synthesis [27]. qRT-PCR was performed using aliquots of cDNA with SYBR Premix EX Taq ${ }^{\mathrm{TM}}$ II (Code. no. RR820A, Takara) and an ABI Prism 7900 (Applied Bio systems, Foster, CA, USA). The primers used, listed in Table 1, were obtained from Sangon Biotech (Shanghai).

\section{Western blot assay}

Cells used for determining HMGB1 protein levels were divided into the following groups: (1) normal control, LPS $(0.25 \mu \mathrm{g} / \mathrm{ml}$ for $24 \mathrm{~h})$, LPS+mip-2 siRNA $(0.25 \mu \mathrm{g} / \mathrm{ml}$ LPS plus $25 \mathrm{nmol} / \mathrm{ml} \mathrm{mip}-2$ siRNA), LPS+scramble siRNA $(0.25 \mu \mathrm{g} / \mathrm{ml}$ LPS plus $25 \mathrm{nmol} / \mathrm{ml}$ scramble siRNA); (2) for RAW264.7 cells: normal control, LPS $(0.25 \mu \mathrm{g} / \mathrm{ml})$, LPS+ MIP-2 antibody $(0.25 \mu \mathrm{g} / \mathrm{ml}$ plus $0.25,0.5$ and $1.0 \mu \mathrm{g} / \mathrm{ml}$ MIP-2 antibody) and LPS+IgG $(0.25 \mu \mathrm{g} / \mathrm{ml}$ plus $1.0 \mu \mathrm{g} / \mathrm{ml} \mathrm{IgG})$; for U937 or TPH-1 cells: normal control, LPS $(0.25 \mu \mathrm{g} / \mathrm{ml})$, LPS+ MIP-2 antibody (0.25 $\mu \mathrm{g} / \mathrm{ml}$ plus $1.0 \mu \mathrm{g} / \mathrm{ml} \mathrm{MIP-2}$ antibody) and LPS+IgG (0.25 $\mu \mathrm{g} / \mathrm{ml}$ plus $1.0 \mu \mathrm{g} /$ ml IgG); (3) normal control, rMIP-2 (30 ng/ml), rMIP-2+ MIP-2 antibody (30 ng/ml rMIP-2 plus $1.0 \mu \mathrm{g} /$ ml MIP-2 antibody), rMIP-2+IgG (30 ng/ml rMIP-2 plus $1.0 \mu \mathrm{g} / \mathrm{ml} \mathrm{IgG);} \mathrm{(4)} \mathrm{normal} \mathrm{control,} \mathrm{LPS} \mathrm{(0.25}$

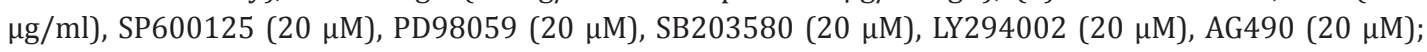
normal control, LPS $(0.25 \mu \mathrm{g} / \mathrm{ml})$, LPS+SP600125 (0.25 $\mathrm{g} / \mathrm{ml}$ LPS plus $20 \mu \mathrm{M}$ SP600125), LPS+PD98059 $(0.25 \mu \mathrm{g} / \mathrm{ml}$ LPS plus $20 \mu \mathrm{M}$ PD98059), LPS+SB203580 (0.25 $\mathrm{gg} / \mathrm{ml}$ LPS plus $20 \mu \mathrm{M}$ SB203580), LPS+LY294002 (0.25 $\mu \mathrm{g} / \mathrm{ml}$ LPS plus $20 \mu \mathrm{M}$ LY294002), LPS+AG490 (0.25 $\mu \mathrm{g} / \mathrm{ml}$ LPS plus $20 \mu \mathrm{M}$ AG490), LPS+LY294002+AG490+SB203580 (0.25 $\mu \mathrm{g} / \mathrm{ml}$ LPS plus $20 \mu \mathrm{M}$ each LY294002, SB203580, and AG490); (5) normal control, LPS (0.25 $\mu \mathrm{g} / \mathrm{ml})$, LPS+ MIP-2 antibody ( $0.25 \mu \mathrm{g} / \mathrm{ml}$ plus $1.0 \mu \mathrm{g} / \mathrm{ml} \mathrm{MIP-2}$ antibody) and LPS+IgG $(0.25 \mu \mathrm{g} / \mathrm{ml}$ plus $1.0 \mu \mathrm{g} / \mathrm{ml}$ IgG).

RAW264.7 cells were exposed to LPS plus $0.25,0.5$ and $1.0 \mu \mathrm{g} / \mathrm{ml}$ anti-MIP-2 antibody for $24 \mathrm{~h}$; RAW264.7 cells were also treated with mip-2 mRNA siRNA for $24 \mathrm{~h}$ and then exposed to LPS for $24 \mathrm{~h}$. U937 cells and THP- 1 cells were exposed to LPS plus $1.0 \mu \mathrm{g} / \mathrm{ml}$ anti-MIP-2 antibody for $24 \mathrm{~h}$. RAW264.7 cells were lysed with RIPA buffer (Millipore, Germany) to prepare total protein samples, and cytoplasmic and nuclear extracts from RAW 264.7 cells were extracted using Nuclear and Cytoplasmic Extraction Reagents (Product No.78835, Thermo Scientific, Rockford, USA). Total protein was used to assess HMGB1 levels by western blotting.

Cells were simultaneously exposed to $1.0 \mu \mathrm{g} / \mathrm{ml}$ anti-MIP-2 antibody and LPS for $24 \mathrm{~h}$, and the collected total protein was used for western blot detection of proteins in different signalling pathways. Cells were also treated with different signalling pathway inhibitors for $2 \mathrm{~h}$ and then exposed to LPS for $24 \mathrm{~h}$; HMGB1 levels in the collected total protein were measured by western blot assay.

After measurement of total, cytoplasmic and nuclear protein concentrations, $20 \mu \mathrm{g}$ cellular protein was separated by $12 \%$ SDS-PAGE and transferred to a polyvinylidene difluoride membrane (Millipore, Billerica, MA). Each membrane was blocked in TBST containing 5\% non-fat milk and incubated overnight, 
at $4{ }^{\circ} \mathrm{C}$ with the following specific primary antibodies: anti-HMGB1 (Product No. ab18256, Abcam, USA), anti- $\beta$-actin (a cytoplasmic protein marker, \#4970, Cell Signaling Technology, USA), anti-proliferating cell nuclear antigen (PCNA, a nuclear protein marker, \#2586, Cell Signaling Technology, USA), anti-Akt1/2/3 (Product No. ab179463, Abcam, USA), anti-phospho-Akt1/2/3 (Product No. ab131443, Abcam, USA), antiSTAT3 (Product No. ab119352, Abcam, USA), anti-phospho-STAT3 (Product No. ab76315, Abcam, USA), rabbit anti-phospho-ERK1/2 (\#4370p, Abcam, USA), rabbit anti-ERK1/2 (\#4695p , Abcam, USA), rabbit anti-phospho-JNK (\#4668p, Abcam, USA), rabbit anti-JNK (\#9258p, Abcam, USA), rabbit anti-phospho-P38 (\#4511, Abcam, USA), rabbit anti-P38 (\#9212p, Abcam, USA), rabbit anti-IкB (Cell Signaling, USA) and rabbit anti-NF-kB p65 (Product No. ab7970, Abcam, USA). After washing with TBST, the membranes were then incubated with horseradish peroxidase-conjugated anti-rabbit or mouse immunoglobulin $\mathrm{G}$ (Southern Biotechnology Associates, Inc., Birmingham, AL, USA) for $1 \mathrm{~h}$ at room temperature. Finally, protein bands were visualized with an enhanced chemiluminescence (ECL) system (KeyGEN Biotechnology, Nanjing, China) and scanned with a Chemiluminescence imaging system (Gel Catcher 2850, China). Relative band intensities were quantified using the software Quantity One v4.62 (Bio-Rad, Inc., Berkeley, CA, USA) to determine the levels of HMGB1 and various proteins (PI3K/Akts, JAKs/STAT3 and MAPKs) of different signalling pathways [28].

Statistical analysis

All experiments were repeated at least three times. Differences between groups were analysed with Student's t-test. SPSS 17.0 software was used for statistical analysis.

\section{Results}

The inhibitory effects of mip-2 siRNA on the mRNA expression levels of mip-2, TNF- $\alpha, I L-1 \beta$, $I L-6, C c l-2, T L R-4$, and iNOS in Raw264.7 cells exposed to $0.25 \mu \mathrm{g} / \mathrm{ml} L P S$ for $2 \mathrm{~h}$

When RAW264.7 cells were exposed to $0.25 \mu \mathrm{g} / \mathrm{ml}$ LPS for $2 \mathrm{~h}$, the mRNA expression levels of mip-2, TNF- $\alpha$, IL-1 $\beta$, IL-6, Ccl-2, TLR-4, and iNOS in the mip-2-siRNA group significantly decreased compared with the scramble siRNA control group, $P<0.01$. The results are shown in Fig. 1 and 2.

Inhibitory effects of mip- 2 siRNA on MIP-2, TNF- $\alpha$, IL-1 $\beta$ and IL-6 secretion by RAW264.7 cells exposed to $0.25 \mu \mathrm{g} / \mathrm{ml}$ LPS for $2 \mathrm{~h}$

The supernatant MIP-2, TNF- $\alpha$, IL- $1 \beta$ and IL- 6 protein levels of the $25 \mathrm{nM}$ mip-2-siRNA groups were significant higher than those of all corresponding control groups $(P<0.01)$, though the levels were still lower than all corresponding control siRNA groups $(P<0.05$ or $P<0.01)$. These results are indicated in Table 2 .

The effects of the MIP-2 antibody and rMIP-2 on the expression levels of TNF- $\alpha$, $I L-1 \beta$ and IL-6 proteins in the supernatant of RAW264.7 cells exposed to LPS

The results (Fig. 3A-C) showed significantly reduced protein levels of proinflammatory cytokines IL- $1 \beta$, TNF- $\alpha$ and IL-6 in the MIP-2 antibody group, whereas these levels were significantly enhanced in the rMIP-2 (with LPS) group compared with the LPS alone group $(P<0.01)$. However, there were no significant differences in IL$1 \beta$, TNF- $\alpha$ and IL- 6 protein levels between the LPS and IgG (Isotype control) groups $(P>0.05)$. Fig. 3D-F illustrates significant differences in IL-1 $\beta$, TNF- $\alpha$ and IL-6 protein

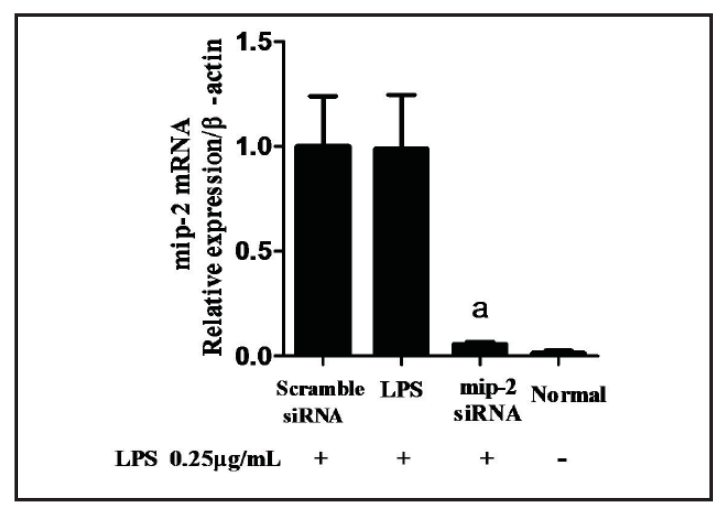

Fig. 1. Inhibitory effects of mip-2 siRNA on mip-2 mRNA expression in RAW264.7 cells exposed to 0.25 $\mu \mathrm{g} / \mathrm{ml}$ LPS. a: compared with the scramble siRNA control group, $P<0.01$. 
Fig. 2. Inhibitory effects of mip-2 siRNA on mRNA expression levels of TNF- $\alpha$, IL- $1 \beta$, IL-6, Ccl-2, TLR4 , and iNOS in RAW264.7 cells exposed to 0.25 $\mu \mathrm{g} / \mathrm{ml}$ LPS for 2 h. a: compared with the scramble siRNA control group, $P<0.01$.

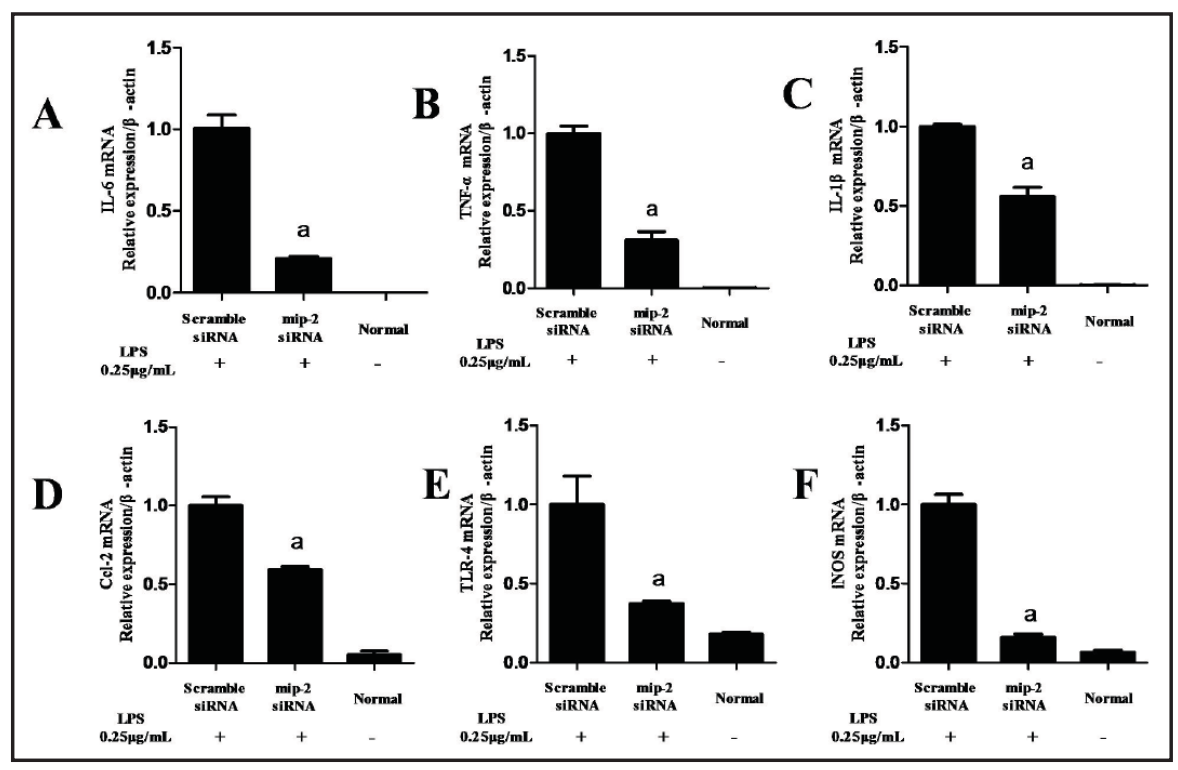

Table 2. The protein expression levels of MIP-2, IL-6, TNF- $\alpha$ and IL- $\beta$ in MC exposed to LPS, LPS plus siRNA and LPS plus control siRNA for $2 \mathrm{~h}$ (mean \pm SD). LPS: lipopolysaccharide; MIP-2: macrophage inflammatory protein-2; IL-6: interleukin-6; IL- $\beta$ : interleukin- $\beta$; TNF- $\alpha$ : tumour necrosis factor- $\alpha$; MC: murine macrophage-like RAW 264.7 cell. a: compared with the control group, $\mathrm{P}<0.01$. b: compared with the control group, $\mathrm{P}<0.05$. c: compared with the corresponding control siRNA group, $\mathrm{P}<0.01$. $\mathrm{d}$ : compared with the corresponding control siRNA group, $\mathrm{P}<0.05$

\begin{tabular}{|c|c|c|c|c|c|c|}
\hline $\begin{array}{l}\text { Groups } \\
\text { LPS }(\mu \mathrm{g} / \mathrm{ml})\end{array}$ & siRNA $(\mathrm{nM})$ & control-siRNA (nM) & $\begin{array}{l}\text { MIP-2 } \\
(\mathrm{ng} / \mathrm{ml})\end{array}$ & $\begin{array}{l}\text { IL-6 } \\
\text { (ng/ml) }\end{array}$ & $\begin{array}{l}\text { TNF- } \alpha \\
\text { (ng/ml) }\end{array}$ & $\begin{array}{l}\text { IL-1 } \beta \\
(\mathrm{ng} / \mathrm{ml})\end{array}$ \\
\hline 0 & 0 & & $0.38 \pm 0.04$ & $0.02 \pm 0.01$ & $0.02 \pm 0.001$ & $0.52 \pm 0.01$ \\
\hline 0.0625 & 0 & & $18.94 \pm 0.65$ & $11.29 \pm 0.77$ & $1.49 \pm 0.01$ & $22.28 \pm 1.93$ \\
\hline 0.1250 & 0 & & $21.6 \pm 0.12$ & $15.95 \pm 0.22$ & $2.88 \pm 0.06$ & $27.9 \pm 1.59$ \\
\hline 0.2500 & 0 & & $30.39 \pm 0.66$ & $50.09 \pm 1.17$ & $5.80 \pm 0.06$ & $77.64 \pm 2.63$ \\
\hline 0.5000 & 0 & & $36.28 \pm 1.09$ & $92.11 \pm 2.69$ & $9.12 \pm 0.36$ & $123.07 \pm 2.55$ \\
\hline 1.0000 & 0 & & $41.2 \pm 1.33$ & $106.02 \pm 1.7$ & $14.08 \pm 0.47$ & $137.93 \pm 2.78$ \\
\hline 0 & 25 & & $0.44 \pm 0.02$ & $0.02 \pm 0.00$ & $0.02 \pm 0.00$ & $0.52 \pm 0.01$ \\
\hline 0.0625 & 25 & & $0.75 \pm 0.02^{\mathrm{ac}}$ & $2.77 \pm 0.17$ ac & $1.08 \pm 0.03^{\mathrm{ac}}$ & $10.34 \pm 2.35^{\mathrm{ac}}$ \\
\hline 0.1250 & 25 & & $0.9 \pm 0.01^{\mathrm{ac}}$ & $4.37 \pm 0.30^{\mathrm{ac}}$ & $1.82 \pm 0.02^{\mathrm{ac}}$ & $23.34 \pm 0.23^{\mathrm{ad}}$ \\
\hline 0.2500 & 25 & & $0.99 \pm 0.04 \mathrm{ac}$ & $6.34 \pm 0.43^{\mathrm{ac}}$ & $2.43 \pm 0.1^{\mathrm{ac}}$ & $42.38 \pm 1.92^{\mathrm{ac}}$ \\
\hline 0.5000 & 25 & & $1.62 \pm 0.06 \mathrm{ac}$ & $33.18 \pm 1.05^{\text {ac }}$ & $5.45 \pm 0.35^{a c}$ & $84.48 \pm 3.31^{\mathrm{ac}}$ \\
\hline 1.0000 & 25 & & $3.00 \pm 0.13 \mathrm{ac}$ & $29.36 \pm 1.38 \mathrm{ac}$ & $8.66 \pm 0.26 \mathrm{ac}$ & $92.29 \pm 1.61^{\mathrm{ad}}$ \\
\hline 0 & 0 & 25 & $0.47 \pm 0.03$ & $0.02 \pm 0.00$ & $0.02 \pm 0.00$ & $0.61 \pm 0.09$ \\
\hline 0.0625 & 0 & 25 & $20.78 \pm 0.28$ & $11.77 \pm 0.12$ & $1.56 \pm 0.05$ & $23.41 \pm 0.63$ \\
\hline 0.1250 & 0 & 25 & $21.68 \pm 1.32$ & $16.35 \pm 0.25$ & $2.99 \pm 0.05$ & $29.69 \pm 1.50$ \\
\hline 0.2500 & 0 & 25 & $31.72 \pm 1.82$ & $51.29 \pm 1.40$ & $5.45 \pm 0.35$ & $84.48 \pm 3.31$ \\
\hline 0.5000 & 0 & 25 & $37.97 \pm 0.80$ & $94.32 \pm 1.93$ & $9.45 \pm 0.29$ & $129.09 \pm 2.72$ \\
\hline 1.0000 & 0 & 25 & $43.41 \pm 2.05$ & $110.70 \pm 6.03$ & $14.93 \pm 0.24$ & $141.80 \pm 3.82$ \\
\hline
\end{tabular}

levels between the negative control group and rMIP-2 group of RAW264.7 cells not exposed to LPS $(P<0.01)$.

The effects of mip-2 siRNA or the MIP-2 antibody on mRNA or protein expression levels of HMGB1 in RAW264.7, U937 or THP-1 cells exposed to LPS

The results of qRT-PCR and western blot assays (Fig. 4A-B) showed that the mRNA and protein expression levels of HMGB1 in RAW264.7 cells of the mip-2 siRNA group exposed to LPS were significantly lower than those of the scramble siRNA control group $(P<0.05$ or $P<0.01$ ). In addition, the levels of HMGB1 protein expression in RAW264.7 cells in the mip2 -siRNA group exposed to LPS were significantly lower than those in the LPS group $(P<0.05)$. 
Fig. 3. (A-F) The effects of MIP-2 antibody and rMIP-2 on the protein expression levels of TNF- $\alpha$, IL-1 $\beta$ and IL- 6 in the supernatants of RAW264.7 cells in the presence or absence of LPS. Cells were divided into NC (normal control), LPS, Ab (LPS+1.0 $\mu \mathrm{g}$ MIP-2 antibody), IgG (LPS+IgG) and rMIP-2 (with LPS or without LPS) groups. a: compared with the LPS group, $P<0.01$. b: compared with the normal control
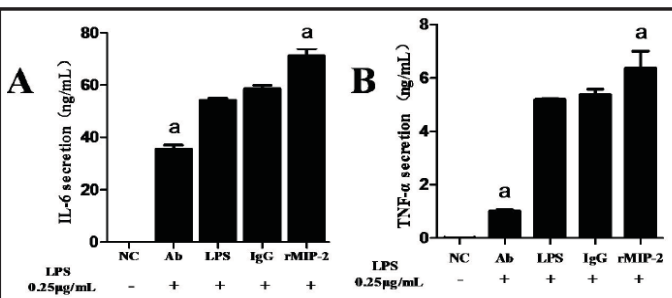

$\underset{0.25 \mathrm{ps} / \mathrm{m} / \mathrm{m}}{\mathrm{1Ps}}$ $\underset{0.25 \mathrm{mg} / \mathrm{m}}{\mathrm{LPS}}$
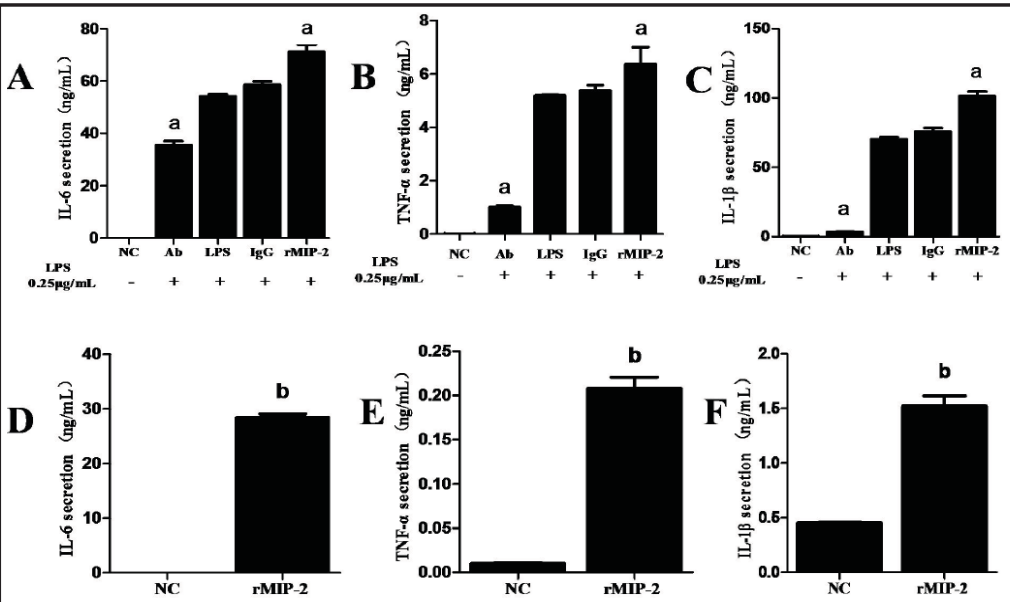

group, $P<0.01$. The results were detected by ELISA assay.

Fig. 4. (A-B) Effects of mip-2 siRNA on mRNA and protein expression levels of HMGB1 in RAW264.7 cells exposed to LPS, as detected by qRT-PCR and western blot assays. Cells were divided into NC (normal control), LPS, scramble (LPS+scramble siRNA control) and mip-2 siRNA (LPS+mip-2 siRNA) groups. a: compared with the scramble siRNA control group, $P<0.05$. b: compared with the scramble siRNA control group, $P<0.01$. c: compared with the LPS group, $P<0.05$; d: compared with the LPS group, $P<0.01$. (C) The effects of the MIP- 2 antibody on protein expression levels of HMGB1 in RAW264.7 cells exposed to LPS, as detected by western blot assay. Cells were divided into NC (normal control), LPS, IgG (LPS+IgG) and three MIP-2 antibody (LPS+0.25 $\mu \mathrm{g}, 0.5 \mu \mathrm{g}, 1.0$ $\mu \mathrm{g} / \mathrm{ml}$ MIP-2 antibody) groups. c: compared with the LPS group, $P<0.05$; d: compared with the LPS group, $P<0.01$. Fig. $4 \mathrm{C}$ represents the average values of three separate experiments. (D-E) The effects of the MIP-2 antibody on the protein expression levels of HMGB1 in U937 and THP-1 cells exposed to LPS as assessed using western blotting. The cells were divided into the NC (normal control), LPS, IgG (LPS+IgG) and MIP-2 antibody (LPS+ $1.0 \mu \mathrm{g} /$ ml MIP-2 antibody) groups. d: compared with the LPS group, $P<0.01$.

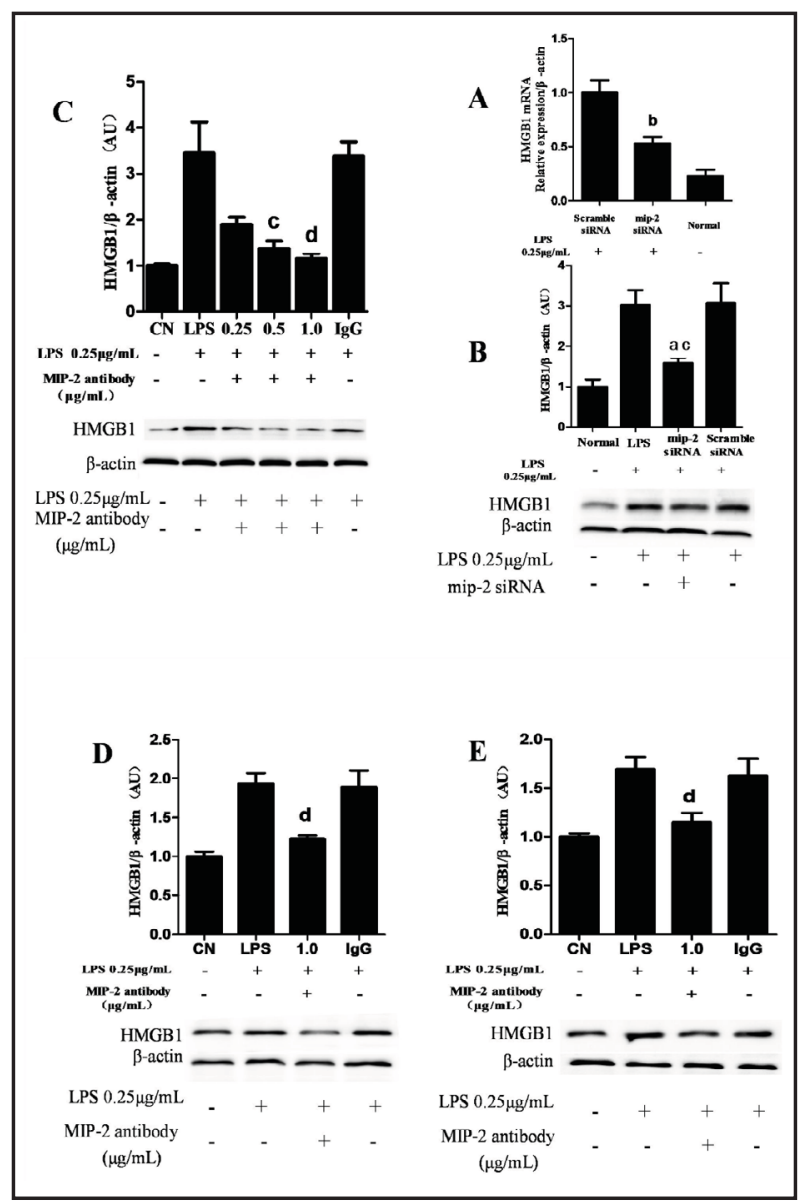

The results of western blot assay showed significantly lower levels of HMGB1 protein expression in RAW264.7 cells (Fig. 4C) of the $0.5 \mu \mathrm{g}$ and $1.0 \mu \mathrm{g}$ anti-MIP-2 antibody groups exposed to LPS compared to the LPS alone group $(P<0.05$ or $P<0.01)$. Furthermore, in U937 (Fig. 4D) or THP-1 (Fig. 4E) cells exposed to LPS, the level of HMGB1 protein expression in the $1.0 \mu \mathrm{g}$ anti-MIP-2 antibody group was significantly lower than that in the LPS group $(P<0.01)$. 
Fig. 5. (A-B) The effects of the MIP-2 antibody and rMIP-2 on the protein expression levels of HMGB1 in the supernatant of RAW264.7 cells. Cells were divided into NC (normal control), LPS, IgG (LPS+IgG), Ab (LPS+1.0 $\mu \mathrm{g} / \mathrm{ml}$ MIP-2 antibody), and 2 rMIP-2 (rMIP-2 in the presence or absence of LPS) groups. a: compared with the LPS group, $P<0.01$. b: compared with the normal control group, $P<0.01$. (C) The effects of the MIP-2 antibody on the protein expression levels of HMGB1 in RAW264.7 cells. Cells were divided into NC (normal control), LPS, IgG (LPS+IgG) and 1.0 (LPS+1. $0 \mu \mathrm{g} / \mathrm{ml}$

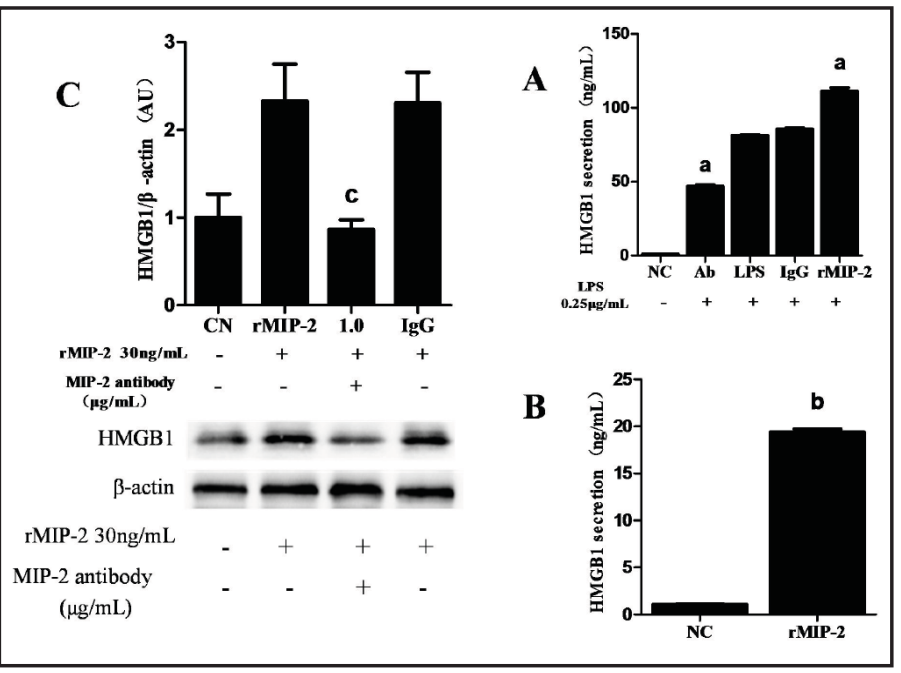

MIP-2 antibody). c: compared with the rMIP-2 group, $P<0.05$.

Fig. 6. The effects of $1.0 \mu \mathrm{g}$ MIP-2 antibody on phosphorylated protein levels of PI3K/Akts, JAKs/STAT3 and MAPKs in RAW264.7 cells exposed to LPS. All protein levels were determined by western blot assay. A: PI3K/Akt protein; B: JAK/STAT3 protein; C-E: 3 MAPK (p38, JNK and ERK) proteins. Cells were divided into NC (normal control), LPS, 1.0 (LPS+1.0 $\mu \mathrm{g} /$ $\mathrm{ml}$ MIP-2 antibody) and IgG (LPS+IgG) groups. a: compared with the LPS group, $P<0.05$; b: compared with the LPS group, $P<0.01$.

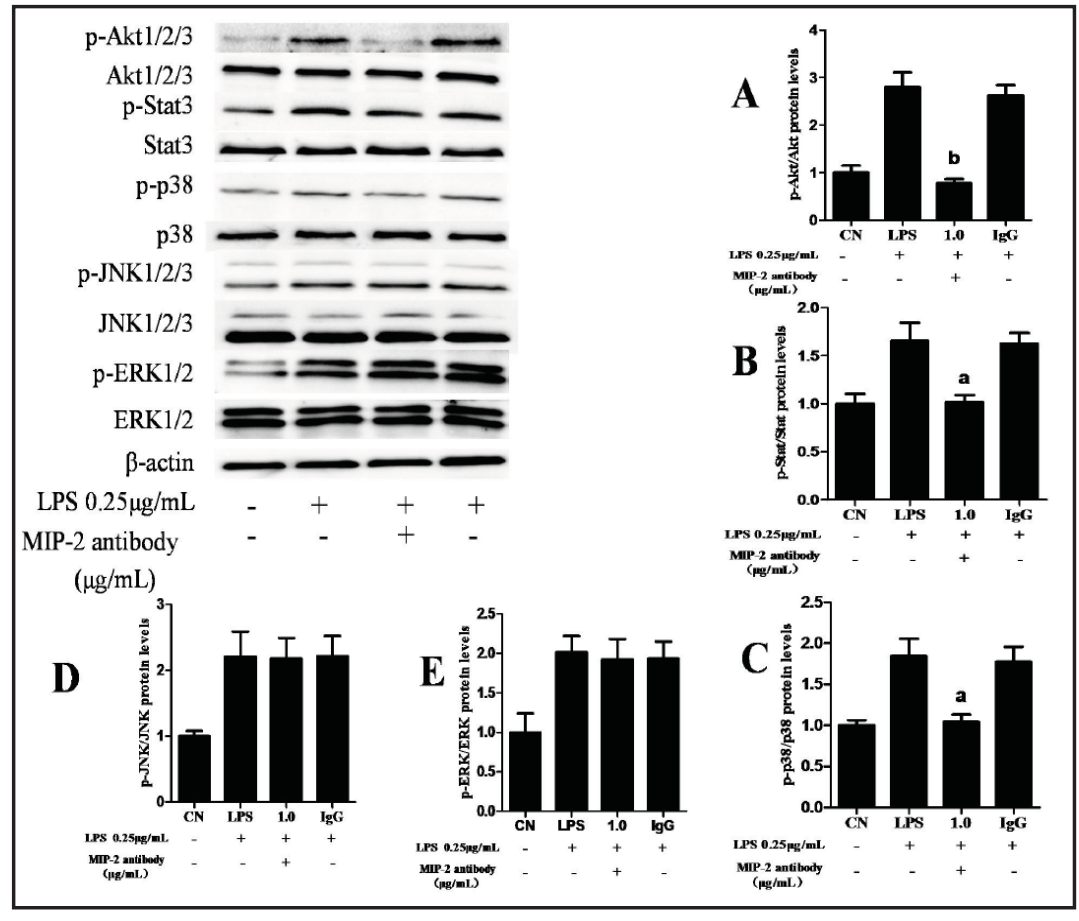

The effects of the MIP-2 antibody and rMIP-2 on the levels of HMGB1 protein expression in RAW264.7 cell cultures

The ELISA results (Fig. 5A) indicated that the HMGB1 protein expression level in the supernatant of RAW264.7 cells exposed to LPS in the MIP-2 antibody group was significantly lower than that in the LPS group but was significantly higher in the rMIP-2 group than in the LPS group $(P<0.01)$. Fig. 5B shows that the HMGB1 protein expression level in the supernatant of RAW264.7 cells not exposed to LPS in the rMIP-2 group was significantly higher than that in the NC group $(P<0.01)$. Furthermore, the results of western blot assay (Fig. 5C) revealed that that the HMGB1 protein expression level in RAW264.7 cells not exposed to LPS in the MIP-2 antibody group was significantly lower than that in the rMIP-2 group $(P<0.05)$. In contrast, there was no significant difference in HMGB1 protein expression level between the rMIP-2 and IgG groups $(P>0.05)$. 


\section{Cellular Physiology Cell Physiol Biochem 2017;42:913-928

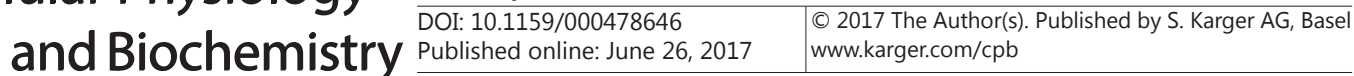

Fig. 7. The effects of inhibitors on the protein expression levels of TNF- $\alpha$, IL-1 $\beta$, IL-6 and HMGB1 in RAW264.7 cell cultures not exposed to LPS. Cells were divided into NC (normal control), LPS, LY (LY294002), AG (AG490), SB (SB203580), PD (PD98059), SP (SP600125) and $A G+S B+L Y$ groups. Fig. 7. $(A-C)$ indicates the results of protein expression levels of TNF- $\alpha$, IL-1 $\beta$ and IL- 6 in culture supernatants; Fig. 7. (G) shows the results of HMGB1 protein expression levels in cultured cells. e: compared with the normal control group, $P<0.01$; f : compared with the normal control group, $P<0.01$. The effects of inhibitors on the protein expression levels of TNF- $\alpha$, IL-1 $\beta$, IL- 6 and HMGB1 in RAW264.7 cell cultures exposed to LPS. Cells
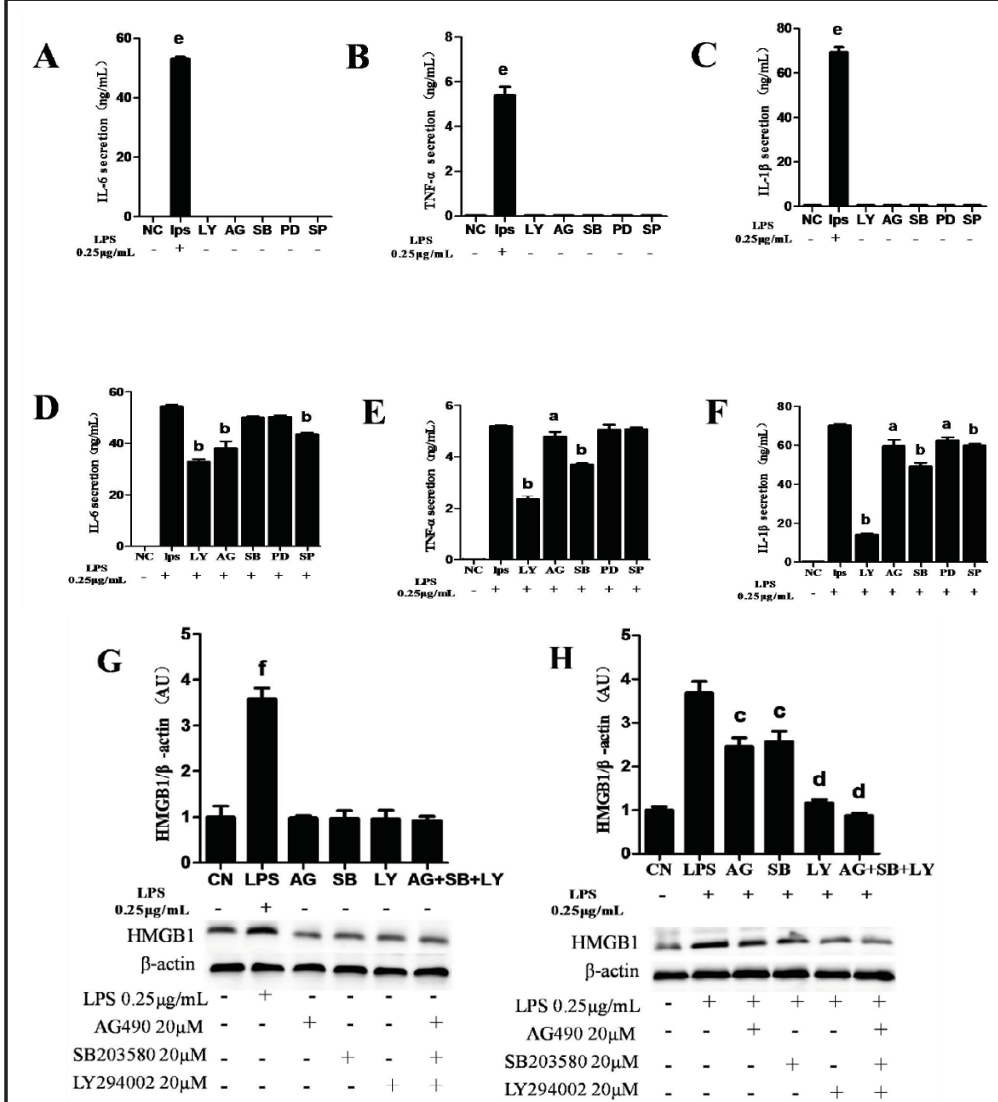

were divided into NC (normal control), LPS, LY (LY294002+LPS), AG (AG490+LPS), SB (SB203580 +LPS), PD (PD98059+LPS), SP (SP600125+LPS) and AG+SB+LY+LPS groups. Fig. 7. (D-F) indicate the results of the protein expression levels of TNF- $\alpha$, IL-1 $\beta$ and IL-6 in culture supernatants; Fig. 7. (H) shows the results of HMGB1 protein expression levels in cultured cells. a: compared with the LPS group, $P<0.05$; b: compared with the LPS group, $P<0.01$. c: compared with the LPS group, $P<0.05$; d: compared with the LPS group, $P<0.01$.

The effects of $1.0 \mu \mathrm{g}$ MIP-2 antibody on levels of phosphorylated PI3K/Akt, JAK/STAT3 and MAPK proteins in RAW264.7 cells exposed to LPS

As shown in Fig. 6, the levels of Akt1/2/3, STAT3 and P38 protein phosphorylation in the $1.0 \mu \mathrm{g}$ MIP-2 antibody group were significantly lower than those in the LPS group $(P<0.05$ or $P<0.01)$. There were no significant differences in phosphorylated protein levels for Akt1/2/3, STAT3 and P38 between the IgG and LPS groups $(P>0.05)$. All protein levels were detected by western blot assay.

The effects of inhibitors on levels of TNF- $\alpha, I L-1 \beta, I L-6$ and HMGB1 protein expression in RAW264.7 cell cultures exposed to LPS

The ELISA results of culture supernatants showed that the protein expression levels of IL- $1 \beta$, TNF- $\alpha$ and IL- 6 in the LPS alone group were significantly increased $(P<0.01)$, but LY294002, AG490, SB203580, PD98059 or SP600125 treatment in the absence of LPS had no significant impact on the expression levels compared with the NC group $(P>0.05$, Fig. $7 \mathrm{~A}-\mathrm{C})$. In the culture supernatants of cells exposed to LPS, the ELISA results showed that the protein expression levels of IL-1 $\beta$ in the LY294002, AG490, SB203580, PD98059 and SP600125 groups were significantly reduced; the protein expression levels of TNF- $\alpha$ in the LY294002, AG490 and SB203580 groups were significantly decreased; and the protein expression levels of IL-6 in the LY294002, AG490 and SP600125 groups were significantly reduced compared with the LPS alone group $(P<0.05$ or $P<0.01$, Fig. 7D-F). 
Fig. 8. The effects of $1.0 \mu \mathrm{g}$ MIP-2 antibody on the expression levels of IкB, cytoplasmic NF- $\mathrm{BB}$ p65 and nuclear NF-kB p65 protein in RAW264.7 cells exposed to LPS. All protein levels were determined by western blot assay. A: ІкB protein; B: nuclear NF-кB p65 protein; C: cytoplasmic NFкB p65 protein. Cells were divided into NC (normal control), LPS, 1.0 (LPS+1.0 $\mu \mathrm{g} / \mathrm{ml}$ MIP-2 antibody) and IgG (LPS+IgG) groups. a: compared with the LPS group, $P<0.01$.

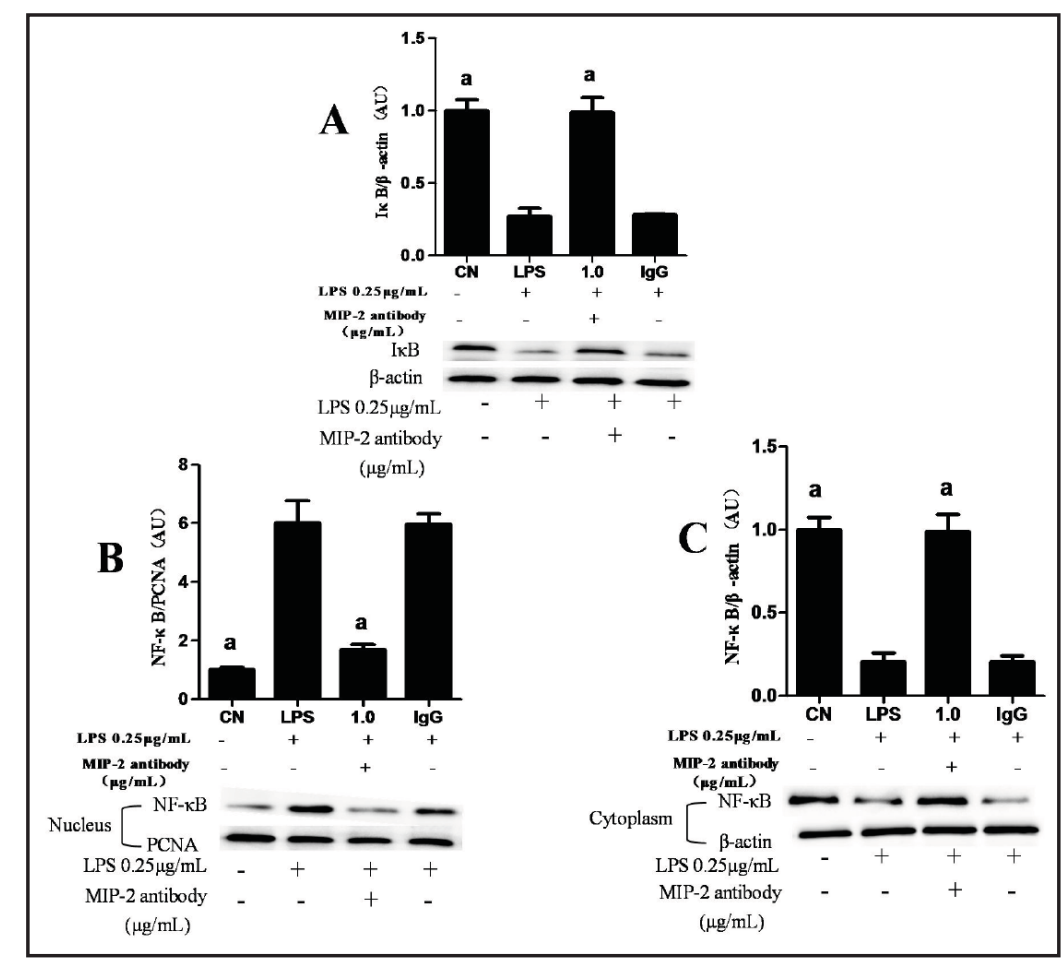

The results of the western blot assay showed that the protein expression levels of HMGB1 in the LPS group were significantly increased $(P<0.01$, Fig. $7 \mathrm{G})$ but that the levels in cells treated with AG490, SB203580, LY294002 or AG490+SB203580+LY294002 in the absence of LPS did not significantly change compared with those in the NC group $(P>0.05$, Fig. 7G). In cells co-treated with LPS and other compounds, the western blot results exhibited that the protein expression levels of HMGB1 in the AG490, SB203580, LY294002 and AG490+SB203580+LY294002 groups were significantly reduced compared with the LPS alone group $(P<0.05$ or $P<0.01$, Fig. $7 \mathrm{H})$.

MIP-2 antibody $(1.0 \mu \mathrm{g})$ inhibits the LPS-induced release of I $\mathrm{KB}$ and nuclear translocation of NF- $\kappa B$ p 65 in RAW264.7 cells

The data shown in Fig. 8 illustrate that IкB protein expression (Fig. 8A) and the concentration of NF- $\kappa B$ p 65 in the cytoplasm (Fig. 8C) of in RAW264.7 macrophages decreased significantly after LPS treatment $(P<0.01)$, and this decline was significantly inhibited by the MIP-2 antibody $(P<0.01)$. Moreover, the amount of NF- $\kappa \mathrm{B}$ p65 in the nucleus (Fig. 8B) was significantly increased $(P<0.01)$ after exposure to LPS, which was also significantly inhibited by the MIP-2 antibody $(P<0.01)$. These results indicate that the MIP- 2 antibody can significantly inhibit the nuclear translocation of NF- $\mathrm{kB}$ p65 and significantly increase the concentration of cytoplasmic NF- $\kappa$ B p65 in macrophages stimulated by LPS. All protein levels were detected by western blot assay.

The effects of EP and MIP-2 antibody on the protein expression levels of TNF- $\alpha, I L-1 \beta$ and IL-6 in the supernatant of RAW264.7 cells exposed to LPS

The ELISA results of the supernatants from cells exposed to LPS showed that the protein expression levels of TNF- $\alpha$ and IL-1 $\beta$ in the 18, 24 and $30 \mathrm{~h}$ EP groups were significantly decreased and that the protein expression levels of IL- 6 in the 12, 18, 24 and $30 \mathrm{~h}$ EP groups were significantly reduced compared with the LPS alone group $(P<0.05$ or $P<0.01$, Fig. 9AC). Fig. 9D-F illustrates that the protein expression levels of TNF- $\alpha$ and IL-1 $\beta$ in the 6, 8, 10 and $12 \mathrm{~h}$ MIP- 2 antibody groups were significantly reduced and that the protein expression levels of IL- 6 in the 4, 6, 8, 10 and $12 \mathrm{~h}$ MIP-2 antibody groups were significantly diminished compared with the LPS alone group $(P<0.05$ or $P<0.01)$. 


\section{Cellular Physiology \begin{tabular}{l|l} 
and Biochemistry Published online: June 26, 2017 & $\begin{array}{l}\text { DO } 2017 \text { The Author(s). Published by S. Karger AG, Basel } \\
\text { www.karger.com/cpb }\end{array}$
\end{tabular}

Fig. 9. (A-F) The effects of EP and an anti-MIP-2 antibody on the protein expression levels of TNF- $\alpha$, IL-1 $\beta$ and IL- 6 in the supernatant of RAW264.7 cells exposed to LPS. Cells were divided into $\mathrm{NC}$ (normal control), 6 EP (LPS+EP for $0,6,12,28,24,30$ h) and seven MIP-2 antibody (LPS+MIP-2 antibody $0,2,4,6,8,10,12$ h) groups. a: compared with the LPS group, $P<0.05$, b: compared with the LPS group,
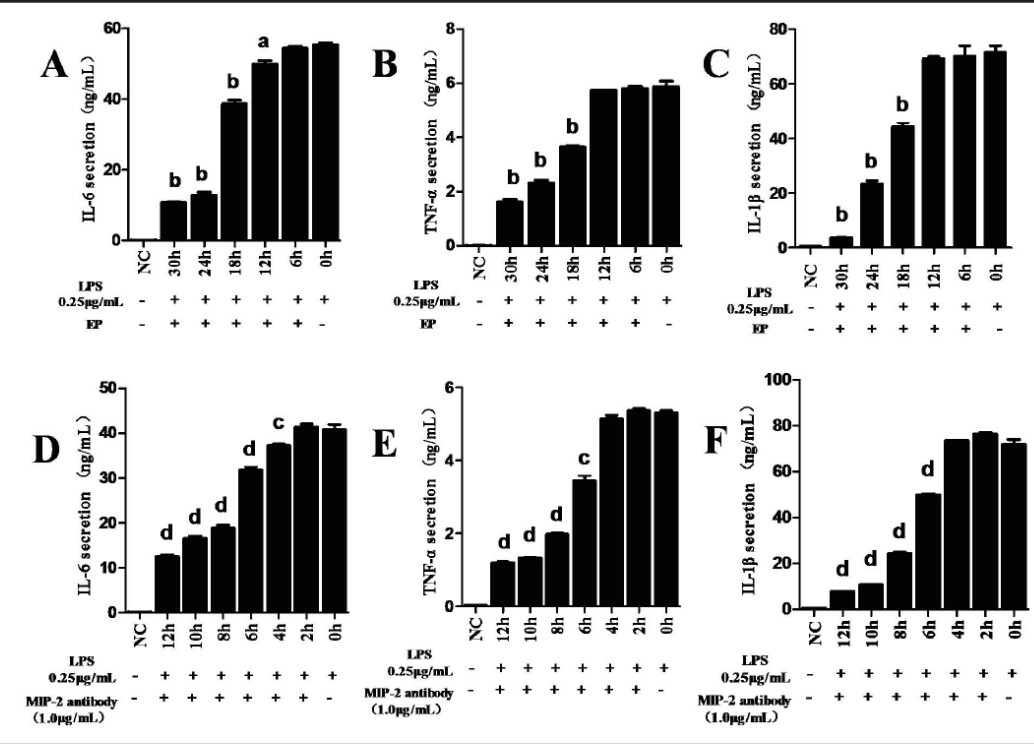

$P<0.01$, c: compared with the LPS group, $P<0.05$; d: compared with the LPS group, $P<0.01$.

\section{Discussion}

Enhanced expression levels of MIP-2, HMGB1, proteins of different signalling pathways and cytokines in macrophage cells exposed to LPS

MIP-2 was initially identified in macrophage cells exposed to LPS. The infiltration of neutrophils from bone marrow to blood requires MIP-2 [29, 30]. Kopydlowski found that MIP-2 mRNA expression of peritoneal macrophages reached peak levels (15-60 folds) at 1-2 $\mathrm{h}$ after exposure to LPS in C3H/OuJ mice [31]. HMGB1 is a critical mediator of many fatal inflammatory responses [32-34]. It is well known that when cells are exposed to LPS, HMGB1 from damaged host cells interacts with receptors (such as RAGE, TLR-9 and TLR-4) on the cell surface, potently activating a wide range of inflammatory responses (production of cytokines), resulting in tissue damage [35, 36].

The present investigation showed that after RAW264.7 cells were exposed to LPS, mip2 mRNA and MIP-2 protein expression increased and that the expression levels of the proinflammatory cytokine HMGB1 (or HMGB1 mRNA) as well as other proteins (p-Akt, p-38, p-JNK, p-ERK and p-STAT3) increased significantly. We also explored cytoplasmic levels of $\mathrm{I} \kappa \mathrm{B}$ and nuclear translocation of NF- $\kappa \mathrm{B}$ p 65 . The results showed that I $\kappa \mathrm{B}$ protein expression decreased significantly after LPS treatment in RAW264.7 macrophages and that the amount of NF- $\kappa B$ p 65 in the nucleus increased significantly while the concentration of NF- $\kappa B$ p 65 in the cytoplasm significantly decreased after exposure to LPS. The results reveal that LPS can increase the translocation of NF- $\mathrm{kB}$ p 65 from the cytoplasm to the nucleus. mRNA or protein expression of other cytokines (IL-6, TNF- $\alpha$, IL-1 $\beta$, Ccl-2, TLR-4, iNOS) was also significantly enhanced at $2 \mathrm{~h}$ or $24 \mathrm{~h}$ after exposure to LPS. Moreover, the expression levels of HMGB1 protein in U937 cells and THP-1cells increased after exposure to LPS. Our results indicated that RAW264.7 cells, U937 cells and THP-1 cells exposed to LPS exhibited a significant response.

Inhibition of MIP-2 can reduce the expression levels of MIP-2, HMGB1, proteins in different signalling pathways and cytokines in RAW264.7 cells exposed to LPS

Exposed to LPS, which is recognized by TLR-4, leads to activation of MyD88-dependent signalling pathways, including those involving mitogen-activated protein kinases (MAPKs), JAKs/STATs and PI3K/Akts. These signalling pathways produce pro-inflammatory cytokines via p38, JNKs, ERKs, and IKK protein kinase cascades, leading to activation of transcription 
factors such as NF- $\kappa \mathrm{B}, \mathrm{AP}-1$ and IRF3, which promote expression of cytokine-encoding genes. Therefore, LPS-mediated production of cytokines (IL-6, TNF- $\alpha$, IL-1 $\beta$, MCP-1, IFN- $\beta$ ) in RAW264.7 cells occurs via PI3K/Akt, MAPK, JAK/STAT pathways [37-42].

Many synthetic drugs, natural products, and antibodies have been developed for suppressing HMGB1, TNF- $\alpha$, IL-1 $\beta$, and IL- 6 release and NO production, and it was found that Res can inhibit expression of HMGB1 in cells exposed to LPS [43-50]. Considering that MIP-2 expression is closely associated with the development of inflammatory responses in RAW264.7 cells exposed to LPS, we assessed the expression levels of HMGB1, proteins of different signalling pathways and cytokines after RAW264.7 cell exposure to LPS or rMIP-2 after suppressing MIP-2 expression to confirm the role of MIP-2 in inflammation induced by LPS or rMIP-2. An anti-MIP-2 antibody and siRNA against mip-2 were used to inhibit MIP-2 expression in RAW264.7 cells exposed to LPS. Not only were MIP-2 expression levels significantly reduced, but the expression levels of HMGB1, different signalling pathway proteins (p-Akts, p-38, and p-STAT3), and cytokines (IL-1 $\beta$, IL-6 and TNF- $\alpha$ ) as well as translocation of NF- $\mathrm{kB}$ p65 from the cytoplasm to nucleus (Fig. 8) were significantly decreased compared with cells only exposed to LPS. Table 2 shows that silencing expression of MIP-2 had a strong inhibitory effect on that of IL-6. In contrast, the effect on TNF- $\alpha$ and IL-1 $\beta$ expression was moderate. This may be because IL- 6 expression increased significantly when the cells were exposed to rMIP-2 (Fig. 3D-F) compared with TNF- $\alpha$ / IL-1 $\beta$; thus, compared with TNF- $\alpha /$ IL-1 $\beta$, IL- 6 expression declined significantly when the cells were exposed to mip-2 siRNA.

Our results suggested that MIP-2 may control HMGB1 and signalling pathways and that MIP-2 may play an important role in inflammatory response in RAW264.7 cells or other macrophages (U937 cells and THP-1 cells) exposed to LPS.

\section{MIP-2 may serve as the target for treating inflammation}

When HMGB1 was silenced in mice using siRNA, fewer pro-inflammatory cytokines were observed compared with the levels in control mice; HMGB1 knockdown also decreased the mRNA and protein levels of IL-1 $\beta$, MIP-2, CXCL12 and CXCR4 in mice and in mononuclear cells [51]. Moreover, neutralization of HMGB1 with an anti-HMGB1 monoclonal antibody strongly inhibited Fas-induced production of MIP-2 and pro-inflammatory cytokines [52]. HMGB1 isolated from cells cultured in the presence of IL-1 $\beta$, IFN- $\gamma$ and TNF- $\alpha$ exerted enhanced pro-inflammatory activity, resulting in increased production of MIP-2 and TNF- $\alpha$ [53]. Therefore, up-regulation of this alarmin could be used to prevent or slow the inflammatory process. MIP-2 is mainly derived from macrophages $[14,54]$; thus, to determine whether LPS-induced MIP-2 production could exert a pro-secretory effect on the expression of HMGB1 and other pro-inflammatory cytokines and whether MIP-2 is a key upstream molecular switch for HMGB1 in RAW264.7 cells, we added rMIP-2 to RAW264.7 cells exposed to LPS. It was observed that rMIP-2 up-regulated the production of some proinflammatory cytokines compared with the LPS alone group. Our results also indicated that rMIP-2 had an enhancing effect on the inflammatory response induced by LPS and could promote the release of HMGB1. Additionally, after adding either MIP-2 antibody or mip2 siRNA to RAW264.7 cells exposed to LPS, expression of MIP-2, HMGB1 and other proinflammatory cytokines (protein or mRNA) was significantly reduced. The results of our study suggest that MIP-2 may act upstream of HMGB1 in LPS-induced RAW264.7 cells. Accordingly, suppression of mip-2 mRNA expression at an early inflammatory stage could be beneficial for controlling inflammation.

The present study reports that specific inhibitors of the p38-MAPK, JAK/STAT3 and PI3K/Akt signalling pathways did not affect the expression of pro-inflammatory cytokines or HMGB1 in RAW264.7 cells. However, in RAW264.7 cells exposed to LPS, those specific inhibitors did significantly reduce the secretion of pro-inflammatory cytokines and HMGB1. Yao, X., et al. reported that JNK and ERK phosphorylation were activated in LPS-treated RAW264.7 cells [55]; however, when adding MIP-2 antibody to RAW264.7 cells exposed to LPS, the JNK and ERK expression levels did not significantly decrease but expression of pro- 
inflammatory cytokines and HMGB1 were significantly diminished. Our study indicated that phosphorylation of p38, STAT3 and Akt was inhibited by the MIP-2 antibody, suggesting that MIP-2 regulates HMGB1 expression not through the JNK and ERK signalling pathways but rather the $\mathrm{p} 38$-MAPK, JAK/STAT3 and PI3K/Akt signalling pathways.

$\mathrm{NF}-\kappa \mathrm{B}$ p65 plays a key regulatory role in the transcription of pro-inflammatory mediators in activated macrophages, including iNOS, IL-1 $\beta$, IL-6 and TNF- $\alpha$ [56-58]. Moreover, NF- $\kappa B$ p65 signalling is also responsible for HMGB1 expression [59]. Under normal conditions, NF$\kappa \mathrm{B}$ p65 is bound to IкB (its endogenous inhibitor) in the cytoplasm, but upon LPS stimulation, I $\kappa \mathrm{B}$ dissociates from the NF- $\kappa \mathrm{B}-\mathrm{I} \kappa \mathrm{B}$ complex and is degraded. This allows the translocation of NF- $\mathrm{BB}$ p65 to the nucleus to activate target genes [60-62]. It has been suggested that

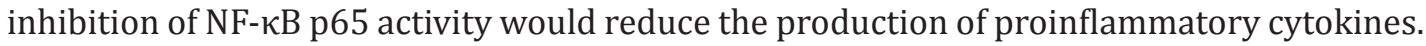
Therefore, in this study, we examined the effects of the MIP-2 antibody on I $\kappa \mathrm{B}$ degradation and nuclear translocation of NF- $\kappa B$ p65 in LPS-stimulated RAW264.7 macrophages. The results showed that LPS-induced I $\kappa B$ degradation and nuclear translocation of NF- $\kappa B$ p65 were significantly reduced by the MIP-2 antibody in LPS-treated RAW264.7 macrophages.

The mechanisms of HMGB1 inhibition by EP have been reported. EP can inhibit HMGB1 acetylation in RAW264.7cells exposed to LPS [63], mediate HMGB1 reduction by altering NF$\kappa B$ DNA-binding activity [64], and specifically inhibit HMGB1 release by inhibiting activation of $\mathrm{p} 38-\mathrm{MAPK}$ or NF- $\mathrm{KB}$ pathways [32].

As stated above, MIP-2 could regulate the inflammation response in macrophages (RAW264.7 cells, U937 and THP-1 cells) exposed to LPS by up-regulating HMGB1. In addition, the MIP-2 antibody and mip-2 siRNA might significantly reduce expression of MIP-2, HMGB1 and other pro-inflammatory cytokine proteins or mRNA in vitro. Thus, MIP-2 may serve as a target for treating inflammation.

\section{Acknowledgments}

This work was supported by grants from the 12-5 State S\&T Projects of China (2012ZX10002007) and Chinese National Natural and Science Foundation (81272679, 81470851).

\section{Disclosure Statement}

The authors declare that there are no conflicts of interest.

\section{References}

1 Kang YJ, Kim SO, Shimada S, Otsuka M, Seit-Nebi A, Kwon BS, Watts TH, Han J: Cell surface 4-1BBL mediates sequential signaling pathways 'downstream' of TLR and is required for sustained TNF production in macrophages. Nat Immunol 2007;8:601-609.

- Jiang Z, Georgel P, Du X, Shamel L, Sovath S, Mudd S, Huber M, Kalis C, Keck S, Galanos C, Freudenberg M, Beutler B: CD14 is required for MyD88-independent LPS signaling. Nat Immunol 2005;6:565-570.

-3 Shirozu K, Hirai S, Tanaka T, Hisaka S, Kaneki M, Ichinose F: Farnesyltransferase inhibitor, tipifarnib, prevents galactosamine/lipopolysaccharide-induced acute liver failure. Shock 2014;42:570-577.

-4 Park SH, Baek SI, Yun J, Lee S, Yoon DY, Jung JK, Jung SH, Hwang BY, Hong JT, Han SB, Kim Y: IRAK4 as a molecular target in the amelioration of innate immunity-related endotoxic shock and acute liver injury by chlorogenic acid. J Immunol 2015;194:1122-1130.

-5 Zhang L, Geng WR, Hu J, Chen XM, Shen YL, Wang LL, Jiang JP, Chen YY: Lipopolysaccharide pretreatment promotes cardiac stem cell migration through heat shock protein 90-dependent beta-catenin activation. Life Sci 2016;153:132-140. 


\section{Cellular Physiology Cell Physiol Biochem 2017;42:913-928

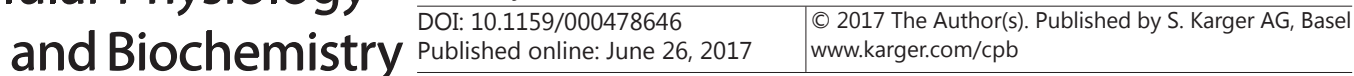 \\ Chaochao et al.: MIP-2 in HMGB1 Secretion}

6 Sallam MY, El-Gowilly SM, Abdel-Galil AG, El-Mas MM: Central GABAA receptors are involved in inflammatory and cardiovascular consequences of endotoxemia in conscious rats. Naunyn Schmiedebergs Arch Pharmacol 2016;389:279-288.

7 Hou Y, Xie G, Liu X, Li G, Jia C, Xu J, Wang B: Minocycline protects against lipopolysaccharide-induced cognitive impairment in mice. Psychopharmacology (Berl) 2016;233:905-916.

$>8$ Ramos CD, Fernandes KS, Canetti C, Teixeira MM, Silva JS, Cunha FQ: Neutrophil recruitment in immunized mice depends on MIP-2 inducing the sequential release of MIP-1alpha, TNF-alpha and LTB(4). Eur J Immunol 2006;36:2025-2034.

-9 Miller MD, Krangel MS: Biology and biochemistry of the chemokines: a family of chemotactic and inflammatory cytokines. Crit Rev Immunol 1992;12:17-46.

10 Nomiyama H, Mera A, Ohneda O, Miura R, Suda T, Yoshie O: Organization of the chemokine genes in the human and mouse major clusters of CC and CXC chemokines: diversification between the two species. Genes Immun 2001;2:110-113.

11 Charo IF, Ransohoff RM: The many roles of chemokines and chemokine receptors in inflammation. N Engl J Med 2006;354:610-621.

12 Hu B, Colletti LM: CXC receptor-2 knockout genotype increases X-linked inhibitor of apoptosis protein and protects mice from acetaminophen hepatotoxicity. Hepatology 2010;52:691-702.

13 Devalaraja RM, Nanney LB, Du J, Qian Q Yu Y, Devalaraja MN, Richmond A: Delayed wound healing in CXCR2 knockout mice. J Invest Dermatol 2000;115:234-244.

14 Zong S, Li K, Zeng G, Fang Y, Zhao J: The Effects of Interleukin-17 (IL-17)-Related Inflammatory Cytokines and A20 Regulatory Proteins on Astrocytes in Spinal Cord Cultured In Vitro. Cell Physiol Biochem 2016;38:1100-1110.

-15 Boppana NB, Devarajan A, Gopal K, Barathan M, Bakar SA, Shankar EM, Ebrahim AS, Farooq SM: Blockade of CXCR2 signalling: a potential therapeutic target for preventing neutrophil-mediated inflammatory diseases. Exp Biol Med (Maywood) 2014;239:509-518.

-16 Tian J, Avalos AM, Mao SY, Chen B, Senthil K, Wu H, Parroche P, Drabic S, Golenbock D, Sirois C, Hua J, An LL, Audoly L, La Rosa G, Bierhaus A, Naworth P, Marshak-Rothstein A, Crow MK, Fitzgerald KA, Latz E, Kiener PA, Coyle AJ: Toll-like receptor 9-dependent activation by DNA-containing immune complexes is mediated by HMGB1 and RAGE. Nat Immunol 2007;8:487-496.

17 Yang H, Wang H, Chavan SS, Andersson U: High Mobility Group Box Protein 1 (HMGB1): The Prototypical Endogenous Danger Molecule. Mol Med 2015;21:S6-S12.

18 Kazama H, Ricci JE, Herndon JM, Hoppe G, Green DR, Ferguson TA: Induction of immunological tolerance by apoptotic cells requires caspase-dependent oxidation of high-mobility group box-1 protein. Immunity 2008;29:21-32.

19 Feghali K, Iwasaki K, Tanaka K, Komaki M, Machigashira M, Ishikawa I, Izumi Y: Human gingival fibroblasts release high-mobility group box-1 protein through active and passive pathways. Oral Microbiol Immunol 2009;24:292-298.

-20 Yamasoba D, Tsubota M, Domoto R, Sekiguchi F, Nishikawa H, Liu K, Nishibori M, Ishikura H, Yamamoto T, Taga A, Kawabata A: Peripheral HMGB1-induced hyperalgesia in mice: Redox state-dependent distinct roles of RAGE and TLR4. J Pharmacol Sci 2016;130:139-142.

21 Lin H, Shen L, Zhang X, Xie J, Hao H, Zhang Y, Chen Z, Yamamoto H, Liao W, Bin J, Cao S, Huang X, Liao Y: HMGB1-RAGE Axis Makes No Contribution to Cardiac Remodeling Induced by Pressure-Overload. PLoS One 2016;11:e0158514.

22 Kollmar O, Menger MD, Schilling MK: Macrophage inflammatory protein-2 contributes to liver resectioninduced acceleration of hepatic metastatic tumor growth. World J Gastroenterol 2006;12:858-867.

23 Zhou H, Ji X, Wu Y, Xuan J, Qi Z, Shen L, Lan L, Li Q, Yin Z, Li Z, Zhao Z: A dual-role of Gu-4 in suppressing HMGB1 secretion and blocking HMGB1 pro-inflammatory activity during inflammation. PLoS One 2014;9:e89634.

24 Yang Q Liu Y, Shi Y, Zheng M, He J, Chen Z: The role of intracellular high-mobility group box 1 in the early activation of Kupffer cells and the development of Con A-induced acute liver failure. Immunobiology 2013;218:1284-1292.

-25 Zhu F, Ding H, Zhu B: Transcriptional profiling of Drosophila S2 cells in early response to Drosophila C virus. Virol J 2013;10:210. 


\section{Cellular Physiology Cell Physiol Biochem 2017;42:913-928

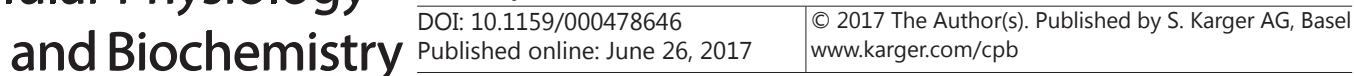 \\ Chaochao et al.: MIP-2 in HMGB1 Secretion}

26 Simoes AE, Pereira DM, Amaral JD, Nunes AF, Gomes SE, Rodrigues PM, Lo AC, D'Hooge R, Steer CJ, Thibodeau SN, Borralho PM, Rodrigues CM: Efficient recovery of proteins from multiple source samples after TRIzol((R)) or TRIzol((R))LS RNA extraction and long-term storage. BMC Genomics 2013;14:181.

27 Marcant A, Denys A, Melchior A, Martinez P, Deligny A, Carpentier M, Allain F: Cyclophilin B attenuates the expression of TNF-alpha in lipopolysaccharide-stimulated macrophages through the induction of B cell lymphoma-3. J Immunol 2012;189:2023-2032.

-28 Liu WX, Zhu HH, Wu W, He JL, Chen Z: Inhibition effect produced by dominant negative mutant fusion protein PreS2-TLM-ScFv-HBcDN on HBV replication in vitro. J Viral Hepat 2012;19:295-300.

-29 Wolpe SD, Sherry B, Juers D, Davatelis G, Yurt RW, Cerami A: Identification and characterization of macrophage inflammatory protein 2. Proc Natl Acad Sci U S A 1989;86:612-616.

30 Kidd BA, Wroblewska A, Boland MR, Agudo J, Merad M, Tatonetti NP, Brown BD, Dudley JT: Mapping the effects of drugs on the immune system. Nat Biotechnol 2016;34:47-54.

-31 Kopydlowski KM, Salkowski CA, Cody MJ, van Rooijen N, Major J, Hamilton TA, Vogel SN: Regulation of macrophage chemokine expression by lipopolysaccharide in vitro and in vivo. J Immunol 1999;163:15371544.

- 32 Ulloa L, Ochani M, Yang H, Tanovic M, Halperin D, Yang R, Czura CJ, Fink MP, Tracey KJ: Ethyl pyruvate prevents lethality in mice with established lethal sepsis and systemic inflammation. Proc Natl Acad Sci U S A 2002;99:12351-12356.

-33 Lutz W, Stetkiewicz J: High mobility group box 1 protein as a late-acting mediator of acute lung inflammation. Int J Occup Med Environ Health 2004;17:245-254.

-34 Shojaei F, Wu X, Malik AK, Zhong C, Baldwin ME, Schanz S, Fuh G, Gerber HP, Ferrara N: Tumor refractoriness to anti-VEGF treatment is mediated by CD11b+Gr1+ myeloid cells. Nat Biotechnol 2007;25:911-920.

-35 Paulson JC, Kawasaki N: Sialidase inhibitors DAMPen sepsis. Nat Biotechnol 2011;29:406-407. Smith KT, Workman JL: Introducing the acetylome. Nat Biotechnol 2009;27:917-919.

Bandow K, Kusuyama J, Shamoto M, Kakimoto K, Ohnishi T, Matsuguchi T: LPS-induced chemokine expression in both MyD88-dependent and -independent manners is regulated by Cot/Tpl2-ERK axis in macrophages. FEBS Lett 2012;586:1540-1546.

-38 Iwasaki A, Medzhitov R: Control of adaptive immunity by the innate immune system. Nat Immunol 2015;16:343-353.

-39 Voss OH, Murakami Y, Pena MY, Lee HN, Tian L, Margulies DH, Street JM, Yuen PS, Qi CF, Krzewski K, Coligan JE: Lipopolysaccharide-Induced CD300b Receptor Binding to Toll-like Receptor 4 Alters Signaling to Drive Cytokine Responses that Enhance Septic Shock. Immunity 2016;44:1365-1378.

-40 Gaidt MM, Ebert TS, Chauhan D, Schmidt T, Schmid-Burgk JL, Rapino F, Robertson AA, Cooper MA, Graf T, Hornung V: Human Monocytes Engage an Alternative Inflammasome Pathway. Immunity 2016;44:833846.

41 Qin X, Jiang X, Wang Y, Miao Z, He W, Yang G, Lv Z, Yu Y, Zheng Y: Micheliolide inhibits LPS-induced inflammatory response and protects mice from LPS challenge. Sci Rep 2016;6:23240.

-42 Shin OS, Miller LS, Modlin RL, Akira S, Uematsu S, Hu LT: Downstream signals for MyD88-mediated phagocytosis of Borrelia burgdorferi can be initiated by TRIF and are dependent on PI3K. J Immunol 2009;183:491-498.

43 Tekkanat KK, Maassab H, Miller A, Berlin AA, Kunkel SL, Lukacs NW: RANTES (CCL5) production during primary respiratory syncytial virus infection exacerbates airway disease. Eur J Immunol 2002;32:32763284.

-44 Yang D, Yuan Q Balakrishnan A, Bantel H, Klusmann JH, Manns MP, Ott M, Cantz T, Sharma AD: MicroRNA125b-5p mimic inhibits acute liver failure. Nat Commun 2016;7:11916.

45 Conrady CD, Zheng M, Mandal NA, van Rooijen N, Carr DJ: IFN-alpha-driven CCL2 production recruits inflammatory monocytes to infection site in mice. Mucosal Immunol 2013;6:45-55.

46 Ishimoto T, Takei Y, Yuzawa Y, Hanai K, Nagahara S, Tarumi Y, Matsuo S, Kadomatsu K: Downregulation of monocyte chemoattractant protein-1 involving short interfering RNA attenuates hapten-induced contact hypersensitivity. Mol Ther 2008;16:387-395.

-47 Lee SH, Kang HY, Kim KS, Nam BY, Paeng J, Kim S, Li JJ, Park JT, Kim DK, Han SH, Yoo TH, Kang SW: The monocyte chemoattractant protein-1 (MCP-1)/CCR2 system is involved in peritoneal dialysis-related epithelial-mesenchymal transition of peritoneal mesothelial cells. Lab Invest 2012;92:1698-1711. 


\section{Cellular Physiology Cell Physiol Biochem 2017;42:913-928

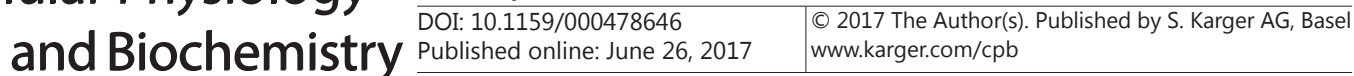 \\ Chaochao et al.: MIP-2 in HMGB1 Secretion}

48 Baeten D, Baraliakos X, Braun J, Sieper J, Emery P, van der Heijde D, McInnes I, van Laar JM, Landewe R, Wordsworth P, Wollenhaupt J, Kellner H, Paramarta J, Wei J, Brachat A, Bek S, Laurent D, Li Y, Wang YA, Bertolino AP, Gsteiger S, Wright AM, Hueber W: Anti-interleukin-17A monoclonal antibody secukinumab in treatment of ankylosing spondylitis: a randomised, double-blind, placebo-controlled trial. Lancet 2013;382:1705-1713.

-49 Yang Y, Li S, Yang Q, Shi Y, Zheng M, Liu Y, Chen F, Song G, Xu H, Wan T, He J, Chen Z: Resveratrol reduces the proinflammatory effects and lipopolysaccharide- induced expression of HMGB1 and TLR4 in RAW264.7 cells. Cell Physiol Biochem 2014;33:1283-1292.

-50 Cheng Y, Wang H, Mao M, Liang C, Zhang Y, Yang D, Wei Z, Gao S, Hu B, Wang L, Cai Q: Escin Increases the Survival Rate of LPS-Induced Septic Mice Through Inhibition of HMGB1 Release from Macrophages. Cell Physiol Biochem 2015;36:1577-1586.

51 McClellan S, Jiang X, Barrett R, Hazlett LD: High-mobility group box 1: a novel target for treatment of Pseudomonas aeruginosa keratitis. J Immunol 2015;194:1776-1787.

-52 Wang F, Lu Z, Hawkes M, Yang H, Kain KC, Liles WC: Fas (CD95) induces rapid, TLR4/IRAK4-dependent release of pro-inflammatory HMGB1 from macrophages. J Inflamm (Lond) 2010;7:30.

53 Sha Y, Zmijewski J, Xu Z, Abraham E: HMGB1 develops enhanced proinflammatory activity by binding to cytokines. J Immunol 2008;180:2531-2537.

54 Abe A, Kuwata T, Yamauchi C, Higuchi Y, Ochiai A: High Mobility Group Box1 (HMGB1) released from cancer cells induces the expression of pro-inflammatory cytokines in peritoneal fibroblasts. Pathol Int 2014;64:267-275.

-55 Yao X, Wu D, Dong N, Ouyang P, Pu J, Hu Q, Wang J, Lu W, Huang J: Moracin C, A Phenolic Compound Isolated from Artocarpus heterophyllus, Suppresses Lipopolysaccharide-Activated Inflammatory Responses in Murine Raw264.7 Macrophages. Int J Mol Sci 2016;17:

-56 Qin ZX, Yu P, Qian DH, Song MB, Tan H, Yu Y, Li W, Wang H, Liu J, Wang Q, Sun XJ, Jiang H, Zhu JK, Lu W, Huang L: Hydrogen-rich saline prevents neointima formation after carotid balloon injury by suppressing ROS and the TNF-alpha/NF-kappaB pathway. Atherosclerosis 2012;220:343-350.

-57 Venkatesan T, Park EJ, Choi YW, Lee J, Kim YK: Anti-inflammatory activity of Ternstroemia gymnanthera stem bark extracts in bacterial lipopolysaccharide-stimulated RAW264.7 murine macrophage cells. Pharm Biol 2017;55:837-846.

58 Xue J, Chen F, Wang J, Wu S, Zheng M, Zhu H, Liu Y, He J, Chen Z: Emodin protects against concanavalin A-induced hepatitis in mice through inhibiting activation of the p38 MAPK-NF-kappaB signaling pathway. Cell Physiol Biochem 2015;35:1557-1570.

59 Wang T, Wei XY, Liu B, Wang LJ, Jiang LH: Effects of propofol on lipopolysaccharide-induced expression and release of HMGB1 in macrophages. Braz J Med Biol Res 2015;48:286-291.

-60 Karuppagounder V, Giridharan VV, Arumugam S, Sreedhar R, Palaniyandi SS, Krishnamurthy P, Quevedo J, Watanabe K, Konishi T, Thandavarayan RA: Modulation of Macrophage Polarization and HMGB1-TLR2/ TLR4 Cascade Plays a Crucial Role for Cardiac Remodeling in Senescence-Accelerated Prone Mice. PLoS One 2016;11:e0152922.

61 Tak PP, Firestein GS: NF-kappaB: a key role in inflammatory diseases. J Clin Invest 2001;107:7-11.

-62 Guo F, Xing Y, Zhou Z, Dou Y, Tang J, Gao C, Huan J: Guanine-nucleotide exchange factor H1 mediates lipopolysaccharide-induced interleukin 6 and tumor necrosis factor alpha expression in endothelial cells via activation of nuclear factor kappaB. Shock 2012;37:531-538.

63 Kim YM, Park EJ, Kim JH, Park SW, Kim HJ, Chang KC: Ethyl pyruvate inhibits the acetylation and release of HMGB1 via effects on SIRT1/STAT signaling in LPS-activated RAW264.7 cells and peritoneal macrophages. Int Immunopharmacol 2016;41:98-105.

64 Su X, Wang H, Zhao J, Pan H, Mao L: Beneficial effects of ethyl pyruvate through inhibiting high-mobility group box 1 expression and TLR4/NF-kappaB pathway after traumatic brain injury in the rat. Mediators Inflamm 2011;2011:807142. 